\title{
Proposals to approximate the pediatric Rome constipation criteria to everyday practice
}

\author{
Helga Verena Leoni MAFFEI ${ }^{1}$ and Mauro Batista de MORAIS ${ }^{2}$
}

Received 23/2/2018 Accepted 27/3/2018

\begin{abstract}
Background - Acceptance of the prevailing pediatric Rome constipation criteria, by primary care physician, is still low. Even for research purposes they have not been universally adopted. Thus, it has been indicated that some re-evaluation of these criteria would be welcome. Objective - The authors aimed to look at the timing of diagnosis and the dietary treatment recommendations in the criteria, to make proposals trying to approximate them to everyday practice. Methods - The literature cited in the Rome criteria was reviewed and the publications pertinent to the subject, searched by Medline up to January 2018, were included. Results - An early diagnosis is fundamental to avoid evolution to bothersome complications and possibly to 'intractable' constipation, but the inclusion of two items of the criteria might hamper it. Thus, one constipation sign/symptom should suffice, usually the easily observable 'painful or hard bowel movements'. Details about dietary fiber recommendations are missing in the criteria, although its increase is usually the first approach in primary care, and overall the data about dietary fiber supplements point to beneficial effects. Conclusion - For diagnosis and treatment of pediatric constipation in primary care, one constipation sign/symptom should suffice. The recommended daily dietary fiber intake, according to the American Health Foundation, should be detailed as a treatment measure, and also for prevention, from weaning on.

HEADINGS - Constipation. Practice guideline. Infant. Child. Adolescent.
\end{abstract}

\section{INTRODUCTION}

Chronic childhood functional constipation (FC) can be considered a public health problem, since it is highly prevalent worldwide, the cure rate is only around $50 \%$ to $60 \%$, recurrence rates are high, and behavior problems are often associated, leading to an important impact on quality of life and to a great economical burden ${ }^{(1-4)}$. Prevalence rates vary a lot, however, and this can be attributed, at least in part, to different definitions used for its diagnosis ${ }^{(4,5)}$. The Rome III criteria for FC, recently substituted by the Rome IV criteria, tried to uniform the diagnostic and treatment criteria ${ }^{(6-9)}$, but its acceptance is still low ${ }^{(10-13)}$; up to $79.5 \%$ of the primary care physician rely on personal experience for diagnosis ${ }^{(12)}$. Reasons for the low acceptance could be the multiple and often changing criteria, the fact that they are based mainly on 'expert opinion', the grade of evidence mostly being low or very low, and/or that they do not fulfill the physician's experience and needs ${ }^{(11,14)}$. In fact, in every day clinical practice often infants present only with straining/pain at defecation of hard and/or scybalous/pebble-like stools, daily or every second day, but the Rome III/IV definition might hamper an early diagnosis at that point ${ }^{(15)}$. In addition, usually the first approach by the primary care physician is to implement a dietary fiber dense diet (DFdd) for these patients $^{(12,16-18)}$, but details about DF recommendations are missing in the criteria. Even for research purposes, the Rome criteria are not universally adopted ${ }^{(19)}$. Thus, it has recently been indicated that some re-evaluation of the Rome criteria would be welcome ${ }^{(4,10)}$.

Diagnostic and treatment criteria should be able to let constipation be detected at its earliest signs, and to avoid that children evolve to 'intractable' constipation; this condition might end up in surgery or electric stimulation ${ }^{(20)}$, and, of course, all efforts should be made to avoid that an originally functional disorder evolves to such invasive and/or expensive interventions. The question remains, however, whether the evolution to 'intractable' constipation could have been interrupted by early diagnosis, and adequate treatment and follow-up. It has been reported that early therapeutic intervention in infants $(<3$ months of symptoms or $<2$ months of treatment before referral) contributes to the resolution of constipation, that onset of constipation before age 1 year is a poor prognostic sign, and that in constipated children younger than 4 years of age, prognosis is better when the child is treated before age 2 years ${ }^{(1,2,6,7)}$. Furthermore, in children with severe constipation, evidenced by the need for rectal biopsy, a better outcome was associated with an earlier diagnosis ${ }^{(21)}$.

Taking the above cited factors into account, we aimed to look at the timing of diagnosis and the dietary treatment recommendations in the prevailing pediatric Rome constipation criteria ${ }^{(6-9)}$, and to make proposals trying to approximate the criteria to everyday practice.

\section{METHODS}

The references cited in the pediatric Rome constipation criteria II, III, IV ${ }^{(6-9,22)}$ were reviewed. The literature cited in a recent book chapter ${ }^{(23)}$ was updated for Jan 2013-Jan 2018. MEDLINE (PubMed) was searched using the headlines 'constipation children', 'constipation diet'.

Declared conflict of interest of all authors: none

Disclosure of funding: no funding received

1 Universidade Estadual Paulista (UNESP), Faculdade de Medicina de Botucatu, Departamento de Pediatria, Botucatu, SP, Brasil; ${ }^{2}$ Universidade Federal de São Paulo (UNIFESP), Escola Paulista de Medicina, Divisão de Gastroenterologia Pediátrica, São Paulo, SP, Brasil.

Corresponding author: Helga Verena Leoni Maffei. Orcid: 0000-0002-2183-7374. E-mail: vlmaffei@uol.com.br. 


\section{RESULTS AND DISCUSSION}

\section{Timing of diagnosis}

Up to $40 \%$ of $\mathrm{FC}$ begins in infancy, often after weaning $^{(6,16,17,24,25)}$. In Brazilian community studies, $21 \%$ to $22 \%$ of infants already present constipation ${ }^{(17,26)}$. Also, 1/3 to 2/3 of mothers of children attended with constipation refer its onset in the first year of life ${ }^{(16,27-30)}$, and these data are trustable, since in a similar population it has been shown that recalled data were similar to recorded data ${ }^{(31)}$. Van Tilburg et al. ${ }^{(10)}$ also showed this similarity, but agreement between daily dairies and the Rome III questionnaire was poor. However, a recent review, which tried to change childhood constipation paradigm from diagnosis and treatment to prevention, did neither mention weaning as a risk factor nor diagnosis at an early age ${ }^{(4)}$.

In addition, many complications, which often also begin early in life, ensue along time (FIGURE 1) ${ }^{(16)}$. Median age at onset of constipation symptoms was 3 month, but 53 month at first visit, with a median interval of 38 month $^{(16)}$. A similar mean interval of 31 month from median age at onset 27 month to first visit $(57 \%$ $\geq 48$ month) has been reported ${ }^{(32)}$. Had appropriate treatment begun at the early onset age, possibly much suffering could have been avoided, since complications disappeared after successful constipation treatment ${ }^{(16)}$.

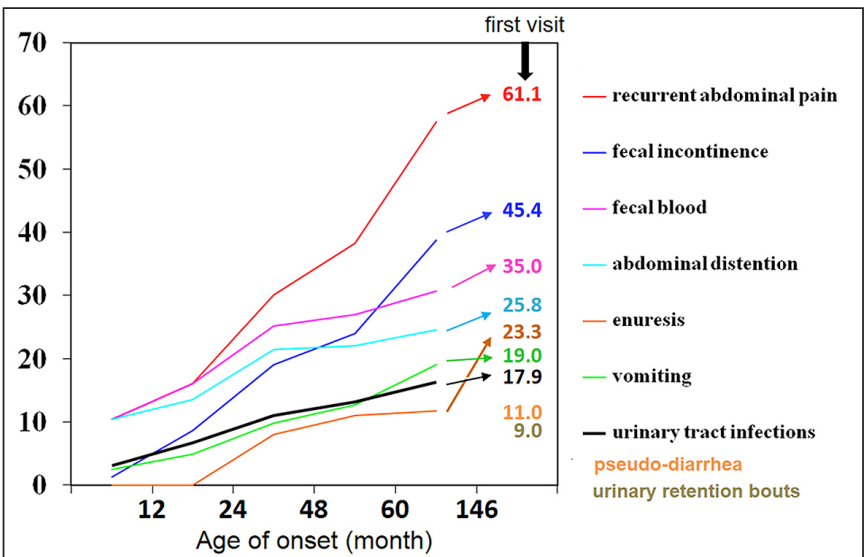

FIGURE 1. Constipation complications: cumulative percentage according to age of onset, in 163 children at the first visit (median age 53 month) to a pediatric gastroenterology outpatient unit. Only data at the first visit are available for pseudo-diarrhea and urinary retention bouts.

Thus, considering that FC frequently begins in infancy, many complications ensue along time, that diagnosis depends on definition, and that early diagnosis is desirable, definition should be able to make an early diagnosis. However, it is difficult to diagnose FC by the Rome III/IV criteria at the very beginning, because two items are needed for diagnosis, in both age ranges ${ }^{(6-9)}$.

Looking at the six items for neonate/toddler in details ${ }^{(6,8)}$ :

- '2 or fewer weekly defecations' is infrequent in weaned constipated infants ${ }^{(13)}$; it occurred in $13 \%$ of $\leq 2$ years old at presentation in a general pediatric clinic ${ }^{(18)}$, and it seems to occur later in the follow-up, as can be suspected from the compilation of Brazilian studies: in tertiary services $43.1 \%-65.8 \%$ of the children with constipation presented $<3$ weekly defecations, whereas this occurred only in $17.3 \%-27.0 \%$ in primary care units/community studies and in $4.0 \%-5.8 \%$ of constipated infants;
- 'impression of excessive fecal retention' may be difficult to value $^{(6,7)}$;

- 'large rectal fecal mass' precludes community surveys; also, a proportion of parents are unwilling to accept a rectal exam, and in fact, it is often omitted in primary care, even when only one additional Rome III criterion is present ${ }^{(33)}$;

- 'fecal incontinence' and 'large diameter stools (that may obstruct the toilet)' are considered irrelevant in infants, since they could be observed only in toilet trained infants ${ }^{(6,8)}$ (except large diameter, a difficult to value item);

- 'painful or hard bowel movements' is easy to observe and can, therefore, be considered the most important item for an early diagnosis in infants/early age. The Bristol Stool Chart( ${ }^{(34)}$ is useful in recognizing the stool characteristics.

Various studies indicate that one item, instead of two, should suffice for an early diagnosis: - in a cohort study from birth up to 4 years, scybalous stools, hard stools and/or difficult evacuation were by far the most frequent constipation signs, whereas $<3$ stools/week occurred in only $2.5 \%$ and $5.5 \%$ at 24 and 48 months respectively, and only $0.7 \%$ of 4 years old children off diapers presented 'feces in clothing ${ }^{3(35)}$; - by the Boston criteria ${ }^{(36)}$, which consider only one item for diagnosis, $22.2 \%$ of 303 infants in three community Health Centers presented FC, whereas this would have been diagnosed in only $2.6 \%$ of them by the Rome III criteria ${ }^{(37)} ;-$ Malowitz et al. ${ }^{(32)}$ used Rome III as the inclusion criteria, but in the discussion they stated 'there is a need for programs for primary care clinicians to educate them on recognizing and treating functional constipation according to published guidelines', to say, delay or difficulty in defecation for $\geq 2$ weeks sufficient to cause significant distress in the patient ${ }^{(38)}$; - only $12.8 \%$ of children seen as outpatients in a secondary-level hospital, with fecal impaction at the rectal exam, presented one additional Rome III criterion ${ }^{(33)}$; - in a recent core outcome set for clinical trials in childhood FC, defecation frequency was less often mentioned as the most important treatment outcome by parents and patients than by healthcare professionals, and 'impression of fecal retention' and 'stools that obstruct the toilet' were almost not mentioned ${ }^{(39)}$.

The Rome III and IV certainly diagnose FC, but besides the diagnostic delay, one must be cautious that - in clinical studies control children are not the reverse of children with constipation. Exemplifying: an infant with five painful, hard and scibalous defecations recorded along 2 weeks in a diary ( 2.5 weekly defecations), no other symptoms, would not be considered constipated by the Rome criteria, and could be wrongly included in the control group.

\section{Treatment}

The multi factorial aspect of FC treatment has to be emphasized; outcome can be unsatisfactory, for instance, if only dietary treatment is approached without disimpaction procedures. Thus, the Rome III/IV recommendations about the initial treatment steps - education, and disimpaction whenever fecal retention/fecaloma is present -, followed by a decreasing laxative schedule are to be endorsed. However, dietary treatment was ignored by Rome III for both age groups, and Rome IV does not mention diet (nor disimpaction) for neonate/toddler ${ }^{(6-8)}$. For $>4$ years old children/ adolescents, Rome IV recommends 'normal' fiber and fluid intake, based on the joint ESPGHAN/NASPGHAN recommendations, which considered evidences "very low" to indicate DF supplements, not mentioning any specific age group ${ }^{(9,14)}$. 
The question is: what is a 'normal' DF intake? According to the initial pediatric Rome II constipation criteria it should be age (years) $+5 \mathrm{~g} /$ day $^{(22)}$. But, following the proposal of the American Health Foundation, this was the minimum DF intake recommended for healthy $\geq 3$ years old children, the considered safe range being age (years)+5-10 g/day. A similar range after weaning, increasing from 4-6 months onwards, was proposed in the same Conference $^{(40,41)}$. According to the US Dietary Reference Intakes the recommended amount for $\geq 1$ year olds is even higher, to say, $14 \mathrm{~g} / 1.000$ $\mathrm{kcal}$, functional fiber being included in the latter amount ${ }^{(42)}$. All recommendations still need to be validated, however. Also the adequate soluble/insoluble DF ratio has to be considered ${ }^{(23)}$. The amount of DF which would be considered adequate for constipated children is unknown, but certainly it should not be lower than for healthy children (perhaps somewhat higher, instead), taking into account that most studies depicted a lower DF intake in constipated than in control children and, therefore, low DF intake is considered a risk factor for $\mathrm{FC}^{(4,23,42)}$. It was also shown that adherence to a 'Health Conscious' dietary pattern was associated with a lower prevalence of constipation at 24 months of age ${ }^{(43)}$, that there could be a bidirectional association between fussy eating and functional constipation in preschool children ${ }^{(44)}$ and that picky eating was associated with a lower DF intake and hard stools ${ }^{(45)}$.

Thus, in our opinion, the recommendation about DF intake in the pediatric Rome constipation criteria needs a more detailed approach, since dietary intervention, including an increase in DF, is almost universal among pediatricians as the first treatment step ${ }^{(12)}$. It is easy to prescribe, not invasive, and has the additional advantage to decrease the risk of obesity, diabetes mellitus, cardiovascular disease, the metabolic syndrome, and several cancers, at the long term $^{(46-48)}$. Considering that almost all population surveys depicted a DF intake below the minimum recommended, for the majority of the children/adolescents ${ }^{(23)}$, it has the additional advantage to be educative for the dietary component of a healthy life style. Impressed leaflets, as presented in FIGURE 2, are helpful.

To help prevent and treat constipation, obesity, diabetis, cardiovascular disease, some sorts of cancer, the family's diet should always contain much dietary fiber

\section{DIETARY FIBER DENSE FOODS}

CEREALS: 6 portions/day, half full-corn: breads (wheat/rye), popcorn, pasta, breakfast cereals, rice, kibbe wheat. Add wheat bran if necessary

VEGETABLES: 3-5 portions/day. Don't throw away what can be eaten

FRUITS: 2-4 portions/day (with bagasse/seeds)

"fresh" unpeeled (not sieved for juice)

dried: coconut, raisins, apricot, etc

OIL SEEDS: 1-2 portions/day: olives, all sorts of nuts and seeds

PULSES: 1 portion/day: beans and other legumes

\section{REMINDERS}

HEALTHY SNACKS: dried fruits and nuts, separate or together, olives SWEETS: add fresh/dried fruits, berries with condensed milk, pumpkin, etc. DRINK WATER WITH DIETARY FIBER DENSE FOODS

Almost NO DIETARY FIBER in watermelon, melon, peeled cucumber DECREASE excess of protein (milk, eggs, meat, etc.), and of junk food

(______ _ _ _ _ _ whenever necessary.

FIGURE 2. Example of impressed leaflets for a dietary fiber rich diet.
Part of the resistance to recommend a DFdd could be the fear of a lower nutrient biodisponibility due to DF. But, adverse effects of overconsumption appear unlikely, except at extremes of intake ${ }^{(49)}$. In line with this, respectively $27.6 \%$ and $17.1 \%$ of healthy community $2-5$ years old children had an age (years) $+5-10 \mathrm{~g} /$ day and $>$ age $+10 \mathrm{~g} /$ day DF intake [somewhat lower proportions after 10 years $(26.4 \%$ and $13.4 \%)$ and also in older children/adolescents ${ }^{(50)}$. Also Kranz et al. ${ }^{(51)}$ presented a proportion of 2-5 years old children above the considered upper limit. In our experience, the bowel habit recovery of children with constipation was significantly associated with DF intake >age $+10 \mathrm{~g} /$ day; this amount was ingested at $57.5 \%$ of their follow-up visits along up to 2 years, without adverse effect on the growth curves ${ }^{(52)}$.

There is a belief that it is difficult to achieve children's and their family's adherence to a DFdd, and several interventions to increase acceptance have been tested ${ }^{(23)}$ : goal setting, stimulate patient's responsibility, point rating, and physician's versus physician's plus dietitian's diet advice. In the latter study, although physician's plus dietitian's advice was somewhat better, detailed physician's dietary advice alone did also significantly increase DF intake ${ }^{(53)}$, and this is also the authors experience ${ }^{(52)}$.

Treatment with polyethylene glycol (PEG) and lactulose were detailed in the 'evidence-based recommendations', but DF intake was not, although the level of evidence for a 'normal' fiber intake (instead of additional fiber), for disimpaction with PEG, as well as for PEG and lactulose for maintenance therapy, were equally graded "very low"(14). It was stated that there are no data to support a DFdd or DF supplements for treating childhood constipation, but there are also no data to refute the claim that they are helpful. In fact, a recent review stated that 'limited evidence suggests that administration of a fiber supplement is more effective than placebo for the treatment of childhood constipation' ${ }^{\text {'(54). }}$. Reported studies about the outcome of constipation treatment, so far, have included children whose diets contained their usual foods or supplementation with mainly soluble (SDF) or insoluble fibers (IDF). In theory, IDF is better for laxation than SDF, and wheat bran, a predominantly IDF with a high pentose content, seems better than cocoa husk, whose main component is cellulose ${ }^{(52,55,56)}$. Data about the outcome of constipated children receiving DF supplementation were recently compiled. It calls attention that in 6/7 studies with IDF supplements, wheat bran was employed ${ }^{(23,42)}$. Overall, notwithstanding methodological aspects in these studies, they should be valued, since all point in the same direction of beneficial effects. In addition, a recent publication showed that green banana biomass can be safely used to reduce laxative doses ${ }^{(57)}$. Thus, supplementation should not be condemned 'a priori', but could be recommended when a DFdd is not sufficiently accepted, or not effective, and for economically deprived populations, who cannot afford full corn products, usually more expensive than the refined ones. It seems much more reasonably to use a food component, like wheat bran (if available), to supplement refined cereals, than to use laxatives over years, and in fact, it is very helpful in our everyday practice. In Brazil - and possibly in many other countries - wheat bran is cheap and tested by governmental entities for food security, since it is included in horse and cattle food ${ }^{(52)}$. Also, no negative influence on biochemical or anthropometric data was shown in the studies in which the supplementation was used ${ }^{(23)}$.

Besides normal fiber diet, normal fluid intake is recommended in childhood $\mathrm{FC}^{(9,14)}$. A classical publication by Loening-Baucke and some guidelines recommended higher water intake as part of 
constipation treatment $\mathrm{t}^{(38,58-60)}$. Although results of clinical assays about this topic are controversial, there is some epidemiological evidence that higher intake of water is associated with lower risk of constipation $^{(61)}$. Nevertheless, when DF intake is increased, a greater amount of water intake is necessary, since DF water adsorption underlies its physiological mechanism of action.

\section{PROPOSALS}

Taking the above considerations into account, the proposals to approximate the pediatric Rome constipation criteria to everyday practice are:

Include prevention, starting at weaning ${ }^{(6,17,43)}$. Besides an adequate formula (whenever economically possible), complementary food containing DF according to Agostoni et al. ${ }^{(41)}$ should be recommended. Had weaning already occurred between age 2-6 month, relactation could be tried as a first step, and, if not successful, poorly sensitizing complementary food containing DF should be anticipated, along with the formula ${ }^{(23)}$. Had weaning occurred before age 2 month, the infant has to be closely observed, to introduce lactulose at the first constipation signs/symptoms.

Diagnosis and treatment should not be postponed: avoid delay in diagnosis, recognizing the initial symptoms and using the Bristol
Stool Chart ${ }^{(34)}$; one constipation sign/symptom should suffice to begin dietary treatment.

Treatment should be as vigorous as possible, with disimpaction (whenever fecal retention/fecaloma and/or complications are present), and at least age (years) $+5-10 \mathrm{~g} /$ day DF. DF supplements, mainly of IDF, should be recommended whenever a DFdd is not sufficiently accepted, or not effective, and for economically deprived populations.

\section{CONCLUSION}

Prevention and early diagnosis of FC are important and should be contemplated in the criteria. In addition, although many studies with emphasis on a DFdd and/or DF supplements fail methodological aspects, DF treatment of constipation should not be neglected, since overall the studies point in the same direction of beneficial effects.

\section{Authors' contribution}

Maffei HVL: wrote the text and approved the final version of the article. Morais MB: critically revised the manuscript and approved the final version of the article to be published.

Maffei HVL, Morais MB. Propostas para aproximar os critérios de Roma para constipação intestinal em pediatria à prática diária. Arq Gastroenterol.

RESUMO - Contexto - O emprego dos prevalecentes critérios de Roma para constipação em pediatria, no atendimento primário de saúde, ainda é baixo.

Mesmo com finalidade de pesquisa, estes critérios não têm sido adotados universalmente. Assim, tem sido indicado que seria bem-vinda alguma revisão de tais critérios. Objetivo - Avaliar criticamente o 'timing' do diagnóstico e as recomendações dietéticas dos critérios, a fim de apresentar propostas que os aproximem da prática clínica diária. Métodos - Foi revisada a literatura citada nos critérios de Roma e foram incluídas as publicações pertinentes ao assunto pesquisadas pela Medline até janeiro 2018. Resultados Diagnóstico precoce é fundamental, a fim de evitar evolução para complicações indesejáveis e possivelmente para constipação dita intratável, mas a necessidade de inclusão de dois itens - segundo os critérios - pode inviabilizá-lo. Assim, um sinal/sintoma seria suficiente, em geral a presença de 'evacuações dolorosas e/ou duras', facilmente observáveis. Ademais, nos critérios faltam detalhes quanto à recomendação sobre fibra alimentar, embora o seu incremento seja usualmente a primeira abordagem no atendimento primário, e no geral os dados sobre suplementos de fibra alimentar apontem para efeitos benéficos. Conclusão - Para diagnóstico de constipação em pediatria no atendimento primário, um sinal/sintoma de constipação deve ser suficiente. A ingestão diária de fibra alimentar, conforme a American Health Foundation, deve ser detalhada para o tratamento da constipação e também como medida preventiva desde o desmame.

DESCRITORES - Constipação intestinal. Guia de prática clínica. Lactente. Criança. Adolescente.

\section{REFERENCES}

1. van Ginkel R, Reitsma JB, Buller HA, van Wijk MP, Taminiau JA, Benninga MA. Childhood constipation: longitudinal follow-up beyond puberty. Gastroenterology. 2003;125:357-63.

2. van den Berg MM, Van Rossum CH, de Lorijn F, Reitsma JB, Di Lorenzo C, Benninga MA. Functional constipation in infants: a follow-up study. J Pediatr. 2005;147:700-4.

3. Pijpers MAM, Bongers MEJ, Benninga MA, Berger MY. Functional constipation in children: a systematic review on prognosis and predictive factors. J Pediatr Gastroenterol Nutr. 2010;50:256-68.

4. Rajindrajith S, Devanarayana NM, Crispus Perera BJ, Benninga MA. Childhood constipation as an emerging public health problem. World J Gastroenterol. 2016;22:6864-75

5. Morais MB, Maffei HVL. Constipation. J Pediatr (Rio J). 2000;76(Suppl 2):S147-56.

6. Hyman PE, Milla PJ, Benninga MA, Davidson GP, Fleisher DF, Taminiau J. Childhood functional gastrointestinal disorders: neonate / toddler. Gastroenterology. 2006;130:1519-26.

7. Rasquin A, DiLorenzo C, Forbes D, Guiraldes E, Hyams JS, Staiano A, et al. Childhood functional gastrointestinal disorders: child/adolescent. Gastroenterology. 2006;130:1527-37.

8. Benninga MA, Nurko S, Faure C, Hyman PE, St James-Roberts I, Schechter NL. Childhood functional gastrointestinal disorders: neonate/toddler. Gastroenterology 2016;150:1443-55.e2.
9. Hyams JS, Di Lorenzo C, Saps M, Shulman RJ, Staiano A, van Tilburg M. Childhood functional gastrointestinal disorders: child/adolescent. Gastroenterology. 2016;150:1456-68.

10. van Tilburg MA, Squires M, Blois-Martin N, Leiby A, Langseder A. Test of the child/adolescent Rome III criteria: agreement with physician diagnosis and daily symptoms. Neurogastroenterol Motil. 2013;25:302-7. e246.

11. Sood MR. Evidence-based diagnosis and treatment of functional constipation: 'are we there yet?' J Pediatr Gastroenterol Nutr. 2015;60:288-9.

12. Scarpato E, Quitadamo P, Roman E, Jojkic-Pavkov D, Kolacek S, Papadopoulou A, et al. Functional gastrointestinal disorders in children: a survey on clinical approach in the Mediterranean area. J Pediatr Gastroenterol Nutr. 2017;64:e142-6.

13. Koppen IJN, Vriesman MH, Tabbers MM, Di Lorenzo C, Benninga MA. Awareness and implementation of the 2014 ESPGHAN/NASPGHAN guideline for childhood functional constipation. J Pediatr Gastroenterol Nutr. 2018;66:732-7.

14. Tabbers MM, DiLorenzo C, Berger MY, Faure C, Langendam MW, Nurko S, et al. Evaluation and treatment of functional constipation in infants and children: evidence-based recommendations from ESPGHAN and NASPGHAN. J Pediatr Gastroenterol Nutr. 2014;58:258-74.

15. Levy EI, Lemmens R, Vandenplas Y, Devreker T. Functional constipation in children: challenges and solutions. Pediatric Health Med Ther. 2017;8:19-27. 
16. Maffei HVL, Moreira FL, Kissimoto M, Chaves SM, Faro SE, Aleixo AM. Clinical and alimentary history of children attending a pediatric gastroenterology outpatient clinic with functional chronic constipation and its possible complications. J Pediatr (Rio J). 1994;70:280-6

17. Aguirre ANC, Vitolo MR, Puccini RF, Morais MB. Constipation in infants: influence of type of feeding and dietary fiber intake. J Pediatr (Rio J). 2002;78:202-8

18. Loening-Baucke V. Prevalence, symptoms and outcome of constipation in infants and toddlers. J Pediatr. 2005;146:359-63.

19. Kuizenga-Wessel S, Benninga MA, Tabbers MM. Reporting outcome measures of functional constipation in children from 0 to 4 years of age. J Pediatr Gastroenterol Nutr. 2015;60:446-56.

20. Hutson JM, Dughetti L, Stathopoulos L, Southwell BR. Transabdominal electrical stimulation (TES) for the treatment of slow-transit constipation (STC) Pediatr Surg Int. 2015;31:445-51.

21. Tran K, Staller K, Macklin E, Goldstein A, Belkind-Gerson J, Kuo B. Need for rectal biopsy for childhood constipation predicts severity of illness and need for laxatives. J Pediatr Gastroenterol Nutr. 2016;62:834-9.

22. Rasquin-Weber A, Hyman P, Cucchiara S, Fleisher D, Hyams J, Milla P, et al Childhood functional gastrointestinal disorders. Gut. 1999;45 Suppl 2:II60-8.

23. Maffei HVL. Dietary fiber and wheat bran in childhood constipation and health In: Watson RR, Preedy VR, Zibadi S. Wheat and rice in disease prevention and health. San Diego: Elsevier (AP), 2014:227-39.

24. Turco R, Miele E, Russo M, Mastroianni R, Lavorgna A, Paludetto R, et al Early-life factors associated with pediatric functional constipation. J Pediatr Gastroenterol Nutr. 2014;58:307-12.

25. Vandenplas Y, Abkari A, Bellaiche M, Benninga M, Chouraqui JP, Cokuðrap F, et al. Prevalence and health outcomes of functional gastro-intestinal symptoms in infants from birth to 12 months of age. J Pediatr Gastroenterol Nutr. 2015;61:531-7.

26. Motta MEFA, Silva GAP. Chronic functional constipation in children: diagnosis and prevalence in a low-income community. J Pediatr (Rio J). 1998;74:451-4

27. Morais MB, Vítolo MR, Aguirre NA, Fagundes-Neto U. Measurement of low dietary fiber intake as a risk factor for chronic constipation in children. J Pediatr Gastroenterol Nutr. 1999;29:132-5.

28. Del Ciampo IRL, Galvão LC, Del Ciampo LA, Fernandes MIM. Prevalence of chronic constipation in children at a primary health care unit. J Pediatr (Rio J) 2002;78:497-502.

29. Inaba MK, Peret-Filho LA, Val AC, Penna FJ. Prevalence and clinical characteristics of chronic constipation in children at a gastroenterology care unit. Pediatria (São Paulo). 2003;25:157-63.

30. Medeiros LCS, Morais MB, Tahan S, Fukushima E, Motta MEFA, Fagundes-Neto U. Clinical characteristics of pediatric patients with chronic constipation according to age group. Arq Gastroenterol. 2007:44:340-4.

31. Borgo HC, Maffei HVL. Recalled and recorded bowel habits confirm early onset and high frequency of constipation in day-care nursery children. Arq Gastroenterol. 2009;46:144-50.

32. Malowitz S, Green M, Karpinski A, Rosenberg A, Hyman PE. Age of onset of functional constipation. J Pediatr Gastroenterol Nutr. 2016;62:600-2.

33. Modin L, Walsted AM, Jakobsen MS. Identifying faecal impaction is important for ensuring the timely diagnosis of childhood functional constipation. Acta Paediatr. 2015;104:838-42.

34. Lewis SJ, Heaton KW. Stool form scale as a useful guide to intestinal transit time. Scand J Gastroenterol. 1997;32:920-4.

35. Mota DM, Barros AJD, Santos I, Matijasevich A. Characteristics of intestinal habits in children younger than 4 years: detecting constipation. J Pediatr Gastroenterol Nutr. 2012;55:451-6.

36. Hyams J, Colletti R, Faure C, Gabriel-Martinez E, Maffei HVL, Morais MB, et al. Functional gastrointestinal disorders: Working group report of the First World Congress of Pediatric Gastroenterology, Hepatology and Nutrition. J Pediatr Gastroenterol Nutr. 2002;35(Suppl 2):S110-7.

37. Souza DS, Tahan S, Morais MB. [Constipation and dietary fiber intake in infants: relation with type of feeding, nutritional status and indicators of body iron] [abstract]. [Article in Portuguese]. Rev Med Minas Gerais. 2012;22 Suppl 3:S35.

38. Constipation Guideline Committee of the American Society for Pediatric Gastroenterology, Hepatology and Nutrition. Evaluation and treatment of constipation in infants and children: recommendations of the North American Society for Pediatric Gastroenterology, Hepatology and Nutrition. J Pediatr Gastroenterol Nutr. 2006;43:e1-13.
39. Kuizenga-Wessel S, Steutel NF, Benninga MA, Devreker T, Scarpato E, Staiano A, et al. Development of a core outcome set for clinical trials in childhood constipation: a study using a Delphi technique. BMJ Paediatrics Open. 2017;1:e000017.

40. Williams CL, Bollella M, Wynder EL. A new recommendation for dietary fiber in childhood. Pediatrics. 1995;96:985-8.

41. Agostoni C, Riva E, Giovannini M. Dietary fiber in weaning foods of young children. Pediatrics. 1995;96:1002-5.

42. Stewart ML, Schroeder NM. Dietary treatments for childhood constipation: efficacy of dietary fiber and whole grains. Nutr Reviews. 2013;71:98-109.

43. Kiefte-de Jong JC, de Vries JH, Escher JC, Jaddoe VW, Hofman A, Raat H, et al Role of dietary patterns, sedentary behaviour and overweight on the longitudinal development of childhood constipation: the Generation R study. Matern Child Nutr. 2013;9:511-23.

44. Tharner A, Jansen PW, Kiefte-de Jong JC, Moll HA, Hofman A, Jaddoe VWV, et al. Bidirectional associations between fussy eating and functional constipation in preschool children. J Pediatr. 2015:166;91-6.

45. Taylor CM, Northstone K, Wernimont SM, Emmett PM. Picky eating in preschool children: Associations with dietary fibre intakes and stool hardness Appetite. 2016:1;100:263-71

46. Carlson JJ, Eisenmann JC, Norman GJ, Ortiz KA, Young PC. Dietary fiber and nutrient density are inversely associated with the metabolic syndrome in US adolescents. J Am Diet Assoc. 2011;111:1688-95.

47. World Cancer Research Fund / American Institute for Cancer Research. Continuous Update Project Report. Food, Nutrition, Physical Activity, and the Prevention of Colorectal Cancer. 2011:1-43. Available from: https://www.wcrf org/sites/default/files/Colorectal-Cancer-2011-Report.pdf.

48. Kranz S, Brauchla M, Slavin JL, Miller KB. What do we know about dietary fiber intake in children and health? The effects of fiber intake on constipation, obesity, and diabetes in children. Adv Nutr. 2012;3:47-53.

49. Aggett PJ, Agostoni C, Axelsson I, Edwards CA, Goulet O, Hernell O, et al Nondigestible carbohydrates in the diets of infants and young children: a commentary by the ESPGHAN Committee on Nutrition. J Pediatr Gastroenterol Nutr. 2003;36:329-37.

50. Saldanha LG. Fiber in the diet of US children: results of national surveys. Pediatrics. 1995;96:994-7.

51. Kranz S, Mitchell DC, Siega-Riz AM, Smiciklas-Wright H. Dietary fiber intake by American preschoolers is associated with more nutrient-dense diets. J Am Diet Assoc. 2005; 105:221-5.

52. Maffei HVL, Vicentini AP. Prospective evaluation of dietary treatment in childhood constipation: high dietary fiber and wheat bran intake are associated with constipation amelioration. J Pediatr Gastroenterol Nutr. 2011;52:55-9.

53. Karagiozoglou-Lampoudi T, Daskalou E, Agakidis C, Savvidou A, Apostolou A, Vlahavas G. Personalized diet management can optimize compliance to a high-fiber, high-water diet in children with refractory functional constipation. J Acad Nutr Diet. 2012;112:725-9.

54. Horvath A, Szajewska H. Probiotics, prebiotics, and dietary fiber in the management of functional gastrointestinal disorders. World Rev Nutr Diet. 2013;108:40-8

55. Cummings JH. The effect of dietary fiber on fecal weight and composition. In: Spiller GA. Handbook of dietary fiber in human nutrition. Boca Raton: CRC Press. 2001:183-252

56. Maffei HVL. Chronic functional constipation: which supplementary fiber to choose? J Pediatr (Rio J). 2004;80:167-8.

57. Cassettari VMG, Machado NC, Lourenção PLTA, Carvalho MA, Ortolan EVP. Combinations of laxatives and green banana biomass on the treatment of functional constipation in children and adolescents: a randomized study. J Pediatr (Rio J). 2018. pii: S0021-7557(17)30638-1. [Epub ahead of print].

58. Loening-Baucke V. Chronic constipation in children. Gastroenterology. 1993; 105:1557-64

59. National Collaborating Centre for Women's and Children's Health (UK). Constipation in children and young people: diagnosis and management of idiopathic childhood constipation in primary and secondary care. London: RCOG Press. 2010:91-149

60. Lindberg G, Hamid SS, Malfertheiner P, Thomsen OO, Fernandez LB, Garisch $\mathrm{J}$, et al. World Gastroenterology Organisation global guideline: Constipation-a global perspective. J Clin Gastroenterol. 2011;45:483-7.

61. Boilesen SN, Tahan S, Dias FC, Melli LCFL, Morais MB. Water and fluid intake in the prevention and treatment of functional constipation in children and adolescents: is there evidence? J Pediatr (Rio J). 2017;93:320-7. 